\title{
The Utilitarian Aspect of the Philosophy of Ecology: The Case of Corporate Social Responsibility
}

\author{
SAYEDEH PARASTOO SAEIDI ${ }^{1}$, MOHD SHAHWAHID HAJI OTHMAN ${ }^{1}$, \\ DALIA ŠTREIMIKIENÉ², SAYYEDEH PARISA SAEIDI ${ }^{3}$, ABBAS MARDANI $^{3}$, \\ NERIJUS STASIULIS ${ }^{4}$ \\ ${ }^{1}$ Department of Economics, Faculty of Economics and Management, Universiti Putra Malaysia, 43400, Serdang, Selangor, Malaysia \\ ${ }^{2}$ Lithuanian Energy Institute, Breslaujos St. 3, 44403 Kaunas \\ ${ }^{3}$ Faculty of Management, Universiti Teknologi Malaysia, 81310, Skudai, Johor Bahru, Malaysia \\ ${ }^{4}$ Department of Philosophy and Cultural Studies, Faculty of Creative Industries, Vilnius Gediminas Technical University, Trakų St. 1, \\ 01132 Vilnius \\ Email: pari.saeidi@gmail.com; msho@econ.upm.edu.my; dalia.streimikiene@khf.vu.It; Saeidi55@gmail.com; nerijus.stasiulis@vgtu.It
}

\begin{abstract}
This study aims to combine the philosophical perspective and the practical ethics of ecology in the everyday with a more pragmatic concept of corporate social responsibility. The importance of the latter is shown to be based in the abandonment of the distinction of subject and object and the development of personal as well as cultural ecological consciousness embedded in the notion of unity between man and nature. This philosophical shift in the consciousness is also reflected in terms of utility. Hence, the study examines whether the relationship between corporate social responsibility and firm's sales growth is mediated by competitive advantage, and whether employees' individual perception in the everyday and beliefs of social responsibility can play a moderating role on CSR-sales growth relationship. The analysis revealed that there is the link between CSR and sales growth and that there is a positive effect of CSR on sales growth which is positively moderated by employees' individual beliefs of social responsibility which has been implied by the ecological consciousness.
\end{abstract}

Keywords: corporate social responsibility, competitive advantage, ecological consciousness, employees individual beliefs, philosophy of ecology

JEL Classification Codes: M5, M21

\section{INTRODUCTION}

In recent years, there has been a growing acknowledgement of the importance of the Corporate Social Responsibility (CSR) and scholars studied firms' socially responsible actions from various perspectives including environmental, economic and social goals (Abdullah, Rashid 2012; Aguinis, Glavas 2012; Calabrese et al. 2013; Crifo, Forget 2015; Hys, Hawrysz 2013; Magrizos, Apospori 2015; Vveinhardt, Andriukaitiene 2016; Juscius, Jonikas 2016). CSR depicts both 
the complexities and multi-faceted connections amongst business communities and societies and it represents the monetary, social and natural effects of business exercises (Jamali et al. 2015).

Therefore there is an inevitable interaction between the environmental, economic and social aspects of every firm's business activities. However, businesses have mostly focused on the economic dimension of firms' activities. In this regard, some scholars (Alafi, Hasoneh 2012; Galbreath, Shum 2012; Kim et al. 2015; Margolis, Walsh 2003; Rowley, Berman 2000; Saeidi et al. 2015) have questioned such an approach and, as a counterargument, they claimed that in raising any revenue, consumers' behaviour has always been a major challenge for firms, so organizations should also give consideration to societies' needs and expectations. Consumers appear to possess a reasonable level of awareness of environmental issues and, therefore, they are now more interested in green products which are considered environment-friendly (Zhao et al. 2014).

Some scholars have tried to examine the effects of perceived CSR on commitments (Farooq et al. 2013, 2013; Peterson 2004; Rego et al. 2010; Stites Michael 2011; Turker 2009), whereas some others have concentrated on the key variables which may constitute the social character structure. They have claimed upon their respective investigations that it is a meaningfully different kind of legislative obligation as it reflects individuals' self-definitions, while commitment may not reflect similarly. Alternatively, they attempted to analyse the impact of CSR on a hierarchically recognizable proof as a way to predict employees' performance (Farooq et al. 2014; Farooq et al. 2013; Glavas, Godwin 2012; Kim et al. 2010; Riketta 2005; van Knippenberg, Sleebos 2006). How CSR may influence organizational attraction to potential employees (Albinger, Freeman 2000; Greening, Turban 2000; Turban, Greening 1997), and how CSR may influence different dispositions among current workers (Choi, Yu 2014; Maignan, Ferrell 2001; Maignan et al. 1999; Valentine, Fleischman 2008) have been some other main foci of CSR-employees studies reported in the literature.

A significant number of studies have considered CSR as an independent factor and employees' outcomes at organizations and societies as dependent factors; mostly, the results have indicated that any CSR effort is likely to foster certain relationships between the organizations and their internal stakeholders (i.e. employees). Notwithstanding, scholars in these studies have obviously failed to recognize that the quality of the relationships identified may depend on how well employees understand and believe social responsibilities in their individual lives. They have also failed to consider the philosophical preconditions of such an understanding which consists in the everyday ecological ethics and the ecological approach towards environment in the everyday.

Thus the study attempts to analyse the previous studies along with extending some notions propagated by these studies by means of connecting philosophical, environmental, economic and social aspects of CSR in relation to improving the firms' profitability. In doing so, a competitive advantage which may result from firms' success in attracting and retaining more satisfied and loyal customers on the market is considered a probable beneficial outcome of being friendly with the environment.

\section{THE ABANDONMENT OF THE SUBJECT-OBJECT DISTINCTION IN THE ECOLOGICAL CONSCIOUSNESS}

In order to measure and promote the genuine agenda of CSR, scholars need a better conceptualization of CSR (Carroll 1999; Tench et al. 2012). Many scholars defined CSR as a company's commitment to minimize or eliminate any potentially harmful effects and maximizing its longrun beneficial impact on the society (Mohr et al. 2001; Scherer, Palazzo 2007; Tench et al. 2012; Thornton, Kvarnström 2015; Wood 2010). CSR is also described as a firm's duty, specifically, 
an ethical responsibility, not only due to legal grounds, but to explore and carefully manage the influences of its internal and external relationships (Kolodinsky et al. 2010).

Carroll's (1979) definition of CSR has been one of the best concepts thus far, as the author not only determines it as the responsibility of the organizations in relation to social benefits, but also consistently distinguishes between firms' profit gaining purposes and related responsibilities of companies to societies (Chen et al. 2012; Lozano 2008; Wood 2010). According to Carroll's (1979) classification, corporate social responsibilities may involve the hosting societies' expectations from the organizations such as economic, cultural, legal, ethical expectations over a specific period of time. Numerous scholars have referred to this definition in their respective studies as indicative of a well-defined classification (Galbreath 2008; Galbreath, Shum 2012; Saeidi et al. 2015; Sheth, Babiak 2010; Shum, Yam 2011). Similarly, this study has adapted Carroll's CSR dimension which was later modified by Maignan et al. (1999) and Maignan and Ferrell $(2000,2001)$ to evaluate an organization's recognition of CSR.

But it is also of crucial importance to consider the philosophical preconditions of our conceptual understanding as well as its relation to a broader context of the development of the ecological consciousness and the ecological ethical approaches in the everyday. The underlying focus must be on the recent abandonment of the distinction between subject and object as well as that of man and nature which shaped the modern discourse itself which in turn has led to the ecological crises that we are now aware of.

The ecological discourse has largely been critical of modernity, its modes of thought and action and its tendencies towards exploitation of nature which was perceived as mechanical by modern science and treated by modern societies as a mere resource to be used and exploited for human ends. However, it is important to note that the mechanistic paradigm of science is for the most part a thing of the past (cf. Stasiulis 2016). Furthermore, as emphasized by Szántó (2009: 45), Western thinking is not inherently directed towards the exploitation of nature because early modern thought did not merely contain these destructive tendencies but also implicated ecological thinking. As Szántó goes on to explain, the gist of the scientific shift in the seventeenth century was the separation of the syntactic from the semantic, of the literal from the symbolic, whence nature began to be seen and treated as ordered according to many relations rather than full of what was now considered merely symbolic and metaphorical meanings. Crucially, these newly discovered relations were not only causal but also ecological (Szántó 2009: 55). The multiple relations between animals and their environment is the basis for today's ecological thinking and they were already emphasized by early modern thinkers alongside the utility of (mechanically modelled and instrumentally treated) nature for human ends (Szántó 2009: 55).

The relatedness, or interconnectedness, of objects to (with) other objects has been emphasized by some important trends in the philosophy of science, one of them being the process philosophy of A. Whitehead (cf. 1978). Another crucial aspect of recent changes in the way we see nature which is also essential to Whitehead's thought is the rejection of the "Cartesian" division of the world into objective (the container of truths) and subjective (the container of meanings) as well as of the perception of reality into the known and the knower. Rather, subjectivity is considered to pervade everything, to be everywhere. This subjectivity of objects consists in their being, indeed, processes which develop as a result of their relationship to others (Carolan 2008: 56-57). All things, from protons to multicellular organisms, are composed of modes of processes, hence nature is about them and interconnections, it is seen as a network of relations. If nature's being deprived of meaning was to blame for the ecological crisis, so reinvesting it with meaningfulness (subjectivity) in this novel manner is of central importance to ecology. 
Another implication of process philosophy for our understanding of the world is that other than "purely scientific" dealings with nature are equally important due to the recognition that what science is able to provide us with is not the complete picture of the world or universal knowledge but rather fragments of essentially interconnected and processual reality. Carolan suggests that we do not rely purely on science in our decision making and see the interconnected all spheres of life, including everyday decisions that contribute to the ecological crisis, and thus he insists that we instil the lost feeling of the interrelatedness of environment precisely in the everyday consciousness, or otherwise ecological policies may not stand a chance of being successful whatsoever (Carolan 2008: 62). Modern modes of theory and practice have been criticized for their over-rationality which was inextricably linked with the privileging of the sense of sight and which resulted in neglect of bodily experiences. One of the major tasks that the thinkers of the 20th c. set for themselves was to critique the "objectified" and "detached" relation to the world and to rediscover the importance and modes of bodily perception, or experience. Ecological consciousness cannot be based merely on the sense of sight (as it were, observing nature through a window) but must get involved with it in a bodily manner (Carolan 2008: 69). Hence, Carolan researches how bodily connections to nature through the practice of farming ("getting one's hands dirty") lead to understanding of nature as a whole and as an interconnected process (Carolan 2008: 67-68). It is important to encourage such "ecological" practices in the everyday because they are necessary for ecology and bound for it. And these different everyday attitudes will benefit the ecological trend as a whole.

Another domain in which old dualisms should be overcome for the sake of ecology is that of justification behind the ecological discourse itself. Usually, the justification has been split into two camps - that of pro-nature traditionalists which take a non-anthropocentric stand and suggest that nature be protected for its intrinsic value and that of pro-human-value environmentalists who have doubted the argumentative or persuasive power of their "idealistic" opponents and claim that their position only rings true to the already converted but the real goal is that of converting many business people, farmers and billions of people living in rural poverty who are either unable or unwilling to move towards change (James 2016: 2014). The new pro-human-value environmentalists tend to emphasize pragmatic values (say, ecosystem services) with the intent of making ecology attractive through arguments of utility, while to this their traditionalist opponents retort that such a stance is in the long run doomed to failure and ecology will nevertheless have to be based on nature's intrinsic value rather than being valued for its being means to anthropocentric ends.

James aptly recognizes that both opposing sides, however, agree in assuming that to say that nature should be protected for our sake is to reduce it to its anthropocentric utility. But this assumption on which the argument itself is based is just wrong. James sees that the instrumentalist approach to nature can be successfully challenged by taking a stance which is anthropocentric and yet not instrumentalist. He calls this stance which avoids the opposition of nature versus human "anthropocentric and constitutive" (James 2016: 213). In developing this view, James dismisses the very opposition between (human) subject and (material) nature which has been rather dominant in the modern West. Conducive to pragmatic anthropocentric ends as protection of nature may be, it does not exclude its being of value in another human-related sense which involves interconnecting the being of man with the being of nature. Of course, what nature in such a case means is not just "purely natural" stuff (a là Rousseau), something wild and pristine but also orchards, hedgerows, heaths, cultural landscapes and all other parts of nature that need to be saved from being harmed, damaged or used up (James 
2016: 216). But this is not to say that here nature is reduced to human utility because the very distinction between human environment and natural environment is missing: "nature is part of something valuable that counts as human rather than natural" (James 2016: 221).

James notices that his stance is superior not only in theoretical terms but also on practical grounds as it is most persuasive and most conducive to ecological decisions and policies. For instance, the arguments which succeeded in subverting the UK Government's intention of selling off all of England's publicly owned forests in the early 2010's were precisely of the kind James supports. That is, they emphasized the unity of nature and social well-being, national identity, cultural heritage as well as everyday existence ${ }^{1}$.

Hence, the current trends of thought tend to favour approaches which do not merely emphasize economic utility and which do not disregard the budding ecological consciousness but take into consideration the interconnection between nature and society as well as the unity between the value of nature and human value.

\section{THE UTILITARIAN VALUE OF THE ECOLOGICAL CONSCIOUSNESS}

The main goal of firms is to create more wealth and profits for their respective shareholders, and the main source of profit undoubtedly comes from sales of products and services, which ultimately comes from a group of satisfied customers. Matzler and Hinterhuber (1998), and later Ahmed et al. (2001), Galbreath and Shum (2012) have defined customer satisfaction as an essential ingredient in contributing to organizations' sustainability and growth, or a measure of how items and services being supplied by organizations may meet or surpass their clients' desires.

Psomas and Fotopoulos (2010) highlighted that customer satisfaction is the main driver which may help companies' quality improvement and the market benefits quite significantly. However, Galbreath and Shum (2012) argued that customer satisfaction itself may not be able to affect firms' financial performance on its own, but by means of the reputation of the concerned firms. Evidence in relation to the verification of this claim is a significant number of researchers who have discovered that corporate reputation and consumer loyalty unequivocally correspond and that they positively affect corporate financial performance (Davies et al. 2003; Galbreath, Shum 2012; Walsh et al. 2006; Walsh et al. 2009). In this regard, Clarkson (1995) has also highlighted that the capacity required to construct a positive outlook can be by means of expanding consumer loyalty which is considered fundamental to companies' survival and performance. In a recent study by Saeidi et al. (2015), they discussed the main significance of customer satisfaction and reputation with the latter culminating relatively in a higher level of firms' competitive advantage. As indicated by their findings, more competitive advantage may bring more financial benefits for firms.

Some scholars (Inoue, Lee 2011; Michelon et al. 2013; Perrini et al. 2012; Russo 2014; Samy et al. 2010) have focused on the new customers' expectations on the market and have noted that in the present competitive market, their expectations on companies' products and services

1 The arguments put forward in the campaign against the sell-off were: 'Forests and woods ... are part of our cultural heritage,' 'Forests and woods are integral to our inherited beliefs and values ... [and] part of our nation's identity', 'England's trees, native woods, plantation forests, wood-pasture and parkland ... are an essential part of the ... social well-being of England', 'In some parts of England, forests and woods are an essential part of local landscape character, giving identity and a sense of place', 'People are very passionate about our forests in Norfolk and identify very strongly that woodlands are part of our local cultural heritage,' 'Forests and woods ... are part of our natural and cultural heritage', 'I feel I am a part of the forest where I live, and the forest is a part of me and it is where I feel at home' (James 2016: 223-224). 
are no longer limited to price and quality alone, owing to societies' level of awareness of the effects that the environment and the surrounding nature may have on their health. In other words, societies now have the disposition to demand more durable and environment-friendly commodities from companies. Along these lines, managers must therefore be aware of the externalities, both positive and negative ones that their exercises may produce for societies, and additionally how buyers may value them. In such a manner, Carroll $(1979,2004)$ asserted that change in the quality of items as a socially capable practice may help upgrade the level of satisfaction among clients. All these may eventually lead shareholders not only to consider firms' monetary performance as the single indicator of firms' success level, but they may also equally evaluate the manner in which these firms carry out their community responsibility programs (Barnett, Salomon 2006). These occurrences have therefore shifted the focus of many businesses from a sole monetary thinking approach to a much wider perspective and they understood that placing both social and environmental aspects should not be considered secondary under their main business goal (Stormer 2003). As a response, firms have now started to care more about protecting the nature and the health of societies by means of employing different environmental management strategies such as CSR to gain more competitive advantage and consequently survive on the market.

To sum up this discussion, considerable focus on social responsibility and community affairs may in turn contribute to better marketing operations (Black et al. 2000). According to McWilliams and Siegel (2001), the main way to deal with the idea of CSR may indicate that organizations may work adjusting themselves to a progression of requests that may help improve a monetary, innovative and legitimate system in which social advantages may take priority over the conventional financial related advantage. In other words, CSR is believed to keep up or enhance both the buyers and societies' prosperity, on the one hand, and generate a favourable image that may positively influence consumers' evaluations and attitudes toward the firms, on the other hand (Luo, Bhattacharya 2006; Saeidi et al. 2015; Sen, Bhattacharya 2001).

In this regard, a few related studies have looked into the relationship between the competitive advantage and CSR. For example, Ogrizek (2002) claimed that clear, concrete, market-driven benefits and competitive advantages can be enjoyed by companies which integrate their business policies with CSR. Furthermore, Husted and Salazar (2006) and Porter and Kramer (2011) argued that CSR projects are usually the results of strategic thinking, wherein companies seeking to transform the potential threats into opportunities by means of creating a competitive advantage in relation to socially and environmentally oriented projects. These findings were supported by a recent study carried out by Saeidi et al. (2015) in which the scholars highlighted the competitive advantage as the main outcome of customer satisfaction after employing CSR. The authors explained that CSR, or being 'green', has become a main indicator for the present customers who are becoming more socially aware and are able to differentiate firms' products or services in their attempts on product selection over competitors.

While some scholars may have reported an association between CSR and firms' financial performance via one of its main antecedents, i.e. customer satisfaction and corporate image, to the knowledge of the researcher, no particular study to date has considered sales growth as its dependent variable to CSR and competitive advantage as its mediator. In reviewing the related literature, certain factors such as corporate image, quality of products or services, market position, growth of the company, market leadership, and differentiation and diversity are the most typical items which have widely been mentioned by various researchers in their attempts to measure competitive advantage (Barney 1991; Bataineh, Zoabi 2011; Chang 2011; Chen et al. 2006; Porter, van der Linde 1995). 
Sustainability is the main goal of any business and employees are considered as the most internal important part of the company's goal achievements (Pornchokchai 2008). This is owing to the fact that employees should be involved in supporting any of the firms' objectives and employees should therefore strive to achieve them. Thus, employees' knowledge, views and attitudes towards any strategies being implemented in organizations may play a very critical role in enhancing their support and, ultimately, firms' success in fulfilling their goals. In relation to environmental management strategies such as CSR, which is not an exception to this principle, employees may indeed have a critical role to play in developing an organization's environmental function. Pornchokchai (2008) labelled employees as the heart of CSR in any organization. Accordingly, employees of decency, capability and of relatively higher moral standards who are aware of the social responsibilities are therefore needed to help organizations to be more successful in achieving their social and environmental objectives.

In this regard, employees can be called as key drivers of the concrete and successful implementations of the organizations' CSR activities. Upon discovering such a development, scholars have paid relatively less attention to employees as the internal stakeholders in the CSR area in comparison with a significant number of studies which have focused on customers as external stakeholders. Therefore, there is a need to examine the effects that CSR may have on this group of stakeholders and vice versa. On this subject, a growing body of studies has reportedly started to examine whether and how CSR may potentially lead to positive employee performance and acceptable work behaviours. For example, Singhapakdi et al. (2015) in the context of Thailand have discovered that employees' quality of work life was positively affected by CSR only for those employees who had a relatively higher level of CSR beliefs. Later, Farooq et al. (2014) attempted to examine the relationship of CSR and knowledge sharing behaviours among employees. They found that CSR undoubtedly influenced employees' organizational identification and learning to share knowledge.

The empirical findings of Lee et al. (2013) suggested that CSR is significantly capable of affecting CSR perceptions and, consequently, employees' attachment and ultimately their performance. They also found a positive relationship between perceptions of CSR and employees' organizational commitments. Moreover, some other authors (Brammer et al. 2007; Peterson 2004; Stites, Michael 2011; Turker 2009) have also argued that CSR perceptions are usually associated with employees' commitment and loyalty. In this regard, Kim et al. (2010) described that organizational commitment and positive perception on CSR among employees are positively associated by means of employees' company identification.

In addition to employees' perceptions on CSR in firms and its effect on their performance, the work environment may also equally have a critical effect on employees' positive views of the firms' performance. In this regard, Bhattacharya et al. (2008) highlighted that employees may prefer to work for companies with a CSR policy. It actually means that CSR may make a company's employer look more attractive and, as a result, it may attract a larger number of highly qualified applicants. In this sense, Albinger and Freeman (2000) claimed that employer attractiveness and corporate social performance are positively related to each other among job seekers' interests. Some other scholars (Greening, Turban 2000; Turban, Greening 1997) have also debated that high corporate social performance may attract job hunters to such particular organizations. As a result, companies with more social responsibilities may actually win by attracting a significant number of candidates and applicants. According to Greening and Turban (2000), one possible underlying reason for a strong relationship between CSR and employer attractiveness is that CSR is a sign about norms of work in firms. 


\section{DISCUSSION}

The idea that a positive link identified between social and financial performance may in turn legitimize the corporate social performance on economic grounds (Margolis et al. 2007) has led to carrying out this study, attempting to examine the relationship between the corporate social responsibility (CSR) and sales growth, which is believed to be the main indicator in evaluating corporate financial performance.

The analysis conducted in this study have confirmed and supported almost every related previous study which found a positive relationship between CSR and different financial performance indicators (Alafi, Hasoneh 2012; Galbreath, Shum 2012; Luo, Bhattacharya 2006; Margolis et al. 2008; Saeidi et al. 2015; Shen, Chang 2008).

The economic utility of CSR was found to depend on a set of broader philosophical as well as conceptual changes in the way we perceive reality and human relation to nature and the environment. The abandonment of the rift between the subjective and the objective was found to be crucial for explaining emergence of ecological thinking as well as accounting for as well as encouraging the ecological perception on the everyday and on the level of workers or employees as well as customers.

Some scholars, i.e. Majeed (2011) and Frynas (2015), identified that gaining a competitive advantage may act as a motivational factor for firms to employ CSR by means of creating superior values for their respective customers. Consequently, other scholars (Chi, Gursoy 2009; Haleem et al. 2015; Jahanshani et al. 2014; James et al. 2015; Loveman 1998; Pan, Nguyen 2015; Simon et al. 2009; Swaminathan et al. 2014; Williams, Naumann 2011) have found that creating a superior value for customers by means of meeting their expectations and needs and attaining a considerable level of client happiness may culminate in higher revenues among firms.

Therefore, many businesses are therefore presently trying to implement different strategies to achieve relatively a higher level of customer satisfaction. This is specifically due to customers presently having the tendency to request for economical and all the other naturally amicable items and services (Gauthier 2005; Van Beurden, Gössling 2008) and assessing organizations in relation to whether the associated demonstrations are in ways which may reliably support the welfare of the communities and societies (Maignan et al. 2005). By means of this, CSR endeavours to create better positions for firms to the extent of focusing on the business sector by means of offering quality items and services at a relatively lower cost (ACCA 2009; Cheng et al. 2014; Jamali 2007, 2010; Jamali, Mirshak 2007; Newell, Muro 2006).

The literature to date has indicated that a relatively higher level of employees' perceptions of CSR may have a significant effect on enhancing the attractiveness of the organizations for job seekers, on the one hand, and improving employees' organizational commitments, on the other. It is worth noting that their operationalized definition of employees' perceptions of CSR is the views that employees hold about the companies' involvement towards social and environmental issues, whereas in the case of this study, it focused on the individual perceptions and beliefs held by employees towards social responsibilities and therefore attempted to examine the moderating effects of employees' individual perceptions and beliefs of social responsibility towards societies in relation to the CSR-sales growth link.

\section{CONCLUSIONS}

Therefore, having more socially and environmentally responsible employees may lead firms to be more successful in implementing social/environmental care strategies and consequently may result in a relatively higher amount of sales and financial performance of companies. 
These findings may notably encourage companies to consider changing the ways by means of which they engage with their stakeholders, recognizing that many customers now reportedly factor practices of environmental, social, economic and corporate responsibilities into their purchasing decisions and many employees may prefer to work for companies with an environmental/social care policy (Bhattacharya et al. 2008).

Taken together, the findings of the conducted analysis pointed to a role for CSR in promoting sales growth indirectly by means of enhancing the competitive advantage, and a role for employees' individual beliefs of social responsibilities in relation to strengthening the positive effects of CSR on firms' sales growth.

Received 8 June 2017

Accepted 23 November 2017

\section{References}

1. Abdullah, M. H.; Rashid, N. 2012. “The Implementation of Corporate Social Responsibility (CSR) Programs and Its Impact on Employee Organizational Citizenship Behavior", International Journal of Business and Commerce 2(1): 67-75.

2. ACCA. 2009. The Importance of Corporate Responsibility. Available at: http://www.accaglobal.com/ public interest/ activities/ library/sustainability/ accounting_sustainability/ archive/ 2005/ 19/ publications/ 2784968 (cited 01.03.2009).

3. Aguinis, H.; Glavas, A. 2012. "What We Know and Don't Know About Corporate Social Responsibility: A Review and Research Agenda", Journal of Management 38(4): 932-968.

4. Ahmed, I.; Gul, S.; Hayat, U.; Qasim, M. 2001. "Service Quality, Service Features and Customer Complaint Handling as the Major Determinants of Customer Satisfaction in Banking Sector: A Case Study of National Bank of Pakistan". Available at: http://www.wbiconpro.com/5\%5B1\%5D.ISHFA.pdf (cited 14.01.2001).

5. Alafi, K.; Hasoneh, A. B. 2012. "Corporate Social Responsibility Associated with Customer Satisfaction and Financial Performance: A Case Study with Housing Banks in Jordan", International Journal of Humanities and Social Science 2(15): 102-115.

6. Albinger, H. S.; Freeman, S. J. 2000. "Corporate Social Performance and Attractiveness as an Employer to Different Job Seeking Populations", Journal of Business Ethics 28: 243-253.

7. Barnett, M. I.; Salomon, R. M. 2006. "Beyond Dichotomy: The Curvilinear Relationship Between Social Responsibility and Financial Performance", Strategic Management Journal 27(11): 1101-1122.

8. Barney, J. B. 1991. "Firm Resources and Sustainable Competitive Advantage", Journal of Management 17(1): 99-120.

9. Bataineh, M. T.; Zoabi, M. A. 2011. “The Effect of Intellectual Capital on Organizational Competitive Advantage: Jordanian Commercial Banks (Irbid District) An Empirical Study", International Bulletin of Business Administration (10): 15-24.

10. Bhattacharya, C. B.; Korschun, D.; Sen, S. 2008. "Using Corporate Social Responsibility to Win the War for Talent", MIT Sloan Management Review 49(2): 37-44.

11. Black, E.; Carnes, T.; Richardson, V. 2000. "The Market Valuation of Corporate Reputation", Corporate Reputation Review 3: 21-31.

12. Brammer, S.; Millington, A.; Rayton, B. 2007. "The Contribution of Corporate Social Responsibility to Organizational Commitment", The International Journal of Human Resource Management 18(10): 1701-1719.

13. Calabrese, A.; Costa, R.; Menichini, T.; Rosati, F.; Sanfelice, G. 2013. "Turning Corporate Social Responsibility-driven Opportunities in Competitive Advantages: A Two-dimensional Model”, Knowledge and Process Management 20(1): 50-58.

14. Carolan, M. S. 2008. "An Ecological Politics of Everyday Life: Placing Flesh on Whitehead's Process Philosophy in Search of "Green" Possibilities", World Views: Global Religions, Culture and Ecology 12(1): 51-73.

15. Carroll, A. B. 1979. "A Three-Dimensional Conceptual Model of Corporate Performance", The Academy of Management Review 4: 497-505.

16. Carroll, A. B. 1999. "Corporate Social Responsibility: Evolution of a Definitional Construct", Business \& Society 38(3): 268-295.

17. Carroll, A. B. 2004. "Managing Ethically with Global Stakeholders: A Present and Future Challenge", The Academy of Management Executive 18: 114-120. 
18. Chang, C. H. 2011. "The Influence of Corporate Environmental Ethics on Competitive Advantage: The Mediation Role of Green Innovation", Journal of Business Ethics 104(3): 361-370.

19. Chen, F.-Y.; Chang, Y.-H.; Lin, Y.-H. 2012. "Customer Perceptions of Airline Social Responsibility and Its Effect on Loyalty", Journal of Air Transport Management 20: 49-51.

20. Chen, Y. S.; Lai, S. B.; Wen, C. T. 2006. "The Influence of Green Innovation Performance on Corporate Advantage in Taiwan", Journal of Business Ethics 67(4): 331-339.

21. Cheng, B.; Ioannou, I.; Serafeim, G. 2014. "Corporate Social Responsibility and Access to Finance", Strategic Management Journal 35(1): 1-23.

22. Chi, C. G.; Gursoy, D. 2009. "Employee Satisfaction, Customer Satisfaction, and Financial Performance: An Empirical Examination", International Journal of Hospitality Management 28(2): 245-253.

23. Choi, Y.; Yu, Y. 2014. "The Influence of Perceived Corporate Sustainability Practices on Employees and Organizational Performance", Sustainability 6(1): 348.

24. Clarkson, M. 1995. "A Stakeholder Framework for Analyzing and Evaluating Corporate Social Performance", Academy of Management Review 20(1): 92-117.

25. Crifo, P.; Forget, V. D. 2015. "The Economics of Corporate Social Responsibility: A Firm-Level Perspective Survey", Journal of Economic Surveys 29(1): 112-130.

26. Davies, G.; Chun, R.; da Silva, R. V.; Roper, S. 2003. Corporate Reputation and Competitiveness. London: Routledge.

27. Farooq, M.; Farooq, O.; Jasimuddin, S. M. 2014. "Employees Response to Corporate Social Responsibility: Exploring the Role of Employees' Collectivist Orientation", European Management Journal 32(6): 916-927.

28. Farooq, O.; Payaud, M.; Merunka, D.; Valette-Florence, P. 2013. “The Impact of Corporate Social Responsibility on Organizational Commitment: Exploring Multiple Mediation Mechanisms", Journal of Business Ethics 125(4): 563-580.

29. Frynas, J. G. 2015. "Strategic CSR, Value Creation and Competitive Advantage", in The Routledge Companion to Non-Market Strategy, eds. T. C. Lawton and T. S. Rajwani. Routledge.

30. Galbreath, J. 2008. The Benefits of Corporate Social Responsibility: An Empirical Study. Paper presented at the ANZAM Conference Proceedings (22nd Annual Conference. Auckland).

31. Galbreath, J.; Shum, P. 2012. "Do Customer Satisfaction and Reputation Mediate the CSR-FP Link? Evidence from Australia", Australian Journal of Management 37(2): 211-229.

32. Gauthier, C. 2005. "Measuring Corporate Social and Environmental Performance: The Extended Life-Cycle Assessment", Journal of Business Ethics 59(1): 199-206.

33. Glavas, A.; Godwin, L. N. 2012. "Is the Perception of 'Goodness' Good Enough? Exploring the Relationship Between Perceived Corporate Social Responsibility and Employee Organizational Identification", Journal of Business Ethics 114(1): 15-27.

34. Greening, D. W.; Turban, D. B. 2000. "Corporate Social Performance as a Competitive Advantage in Attracting a Quality Workforce", Business \& Society 39(3): 254-280.

35. Haleem, F.; Farooq, S.; Boer, H.; Gimenez, C. 2015. The Moderating Role of Stakeholder Pressure in the Relationship Between CSR Practices and Financial Performance in a Globalizing World. Paper presented at the 22nd International EurOMA Conference.

36. Husted, B. W.; De Jesus Salazar, J. 2006. “Taking Friedman Seriously: Maximizing Profits and Social Performance*”, Journal of Management Studies 43(1): 75-91.

37. Hys, K.; Hawrysz, L. 2013. "CSR in Poland as an Important Foundation of Modern Society", Management Studies 1(1): 27-33.

38. Inoue, Y.; Lee, S. 2011. "Effects of Different Dimensions of Corporate Social Responsibility on Corporate Financial Performance in Tourism-Related Industries", Tourism Management 32(4): 790-804.

39. Jahanshani, A. A.; Hajizadeh, G. M. A.; Mirdhamadi, S. A.; Nawaser, K.; Khaksar, S. M. S. 2014. "Study the Effects of Customer Service and Product Quality on Customer Satisfaction and Loyalty", International Journal of Humanities and Social Science 1(7): 253-260.

40. Jamali, D. 2007. "The Case of Strategic Corporate Social Responsibility in Developing Countries", Business and Society Review 112(1): 1-27.

41. Jamali, D. 2010. “The CSR of MNC Subsidiaries in Developing Countries: Global, Local, Substantive or Diluted?" Journal of Business Ethics 93: 181-200.

42. Jamali, D.; Lund-Thomsen, P.; Jeppesen, S. 2015. "SMEs and CSR in Developing Countries", Business \& Society 56(1): 11-22. 
43. Jamali, D.; Mirshak, R. 2007. "Corporate Social Responsibility (CSR): Theory and Practice in a Developing Country Context", Journal of Business Ethics 72(3): 243-262.

44. James, K.; Babin, B. J.; Borges, A. 2015. "Retailer Success: Value and Satisfaction", in Ideas in Marketing: Finding the New and Polishing the Old, ed. K. Kubacki. Springer, 436-438.

45. James, S. P. 2016. "Protecting Nature for the Sake of Human Beings", Ratio (New Series) 29(2): 213227.

46. Juscius, V.; Jonikas, D. 2016. "Measurement Possibilities of the Value Created through Corporate Social Responsibility", Transformations in Business \& Economics 13(39): 53-75.

47. Kim, H.; Hur, W.-M.; Yeo, J. 2015. "Corporate Brand Trust as a Mediator in the Relationship between Consumer Perception of CSR, Corporate Hypocrisy, and Corporate Reputation", Sustainability 7(4): 3683-3694.

48. Kim, H.-R.; Lee, M.; Lee, H.-T.; Kim, N.-M. 2010. "Corporate Social Responsibility and EmployeeCompany Identification”, Journal of Business Ethics 95(4): 557-569.

49. Kolodinsky, R. W.; Madden, T. M.; Zisk, D. S.; Henkel, E. T. 2010. “Attitudes about Corporate Social Responsibility: Business Student Predictors", Journal of Business Ethics 91(2): 167-181.

50. Lee, E. M.; Park, S.-Y.; Lee, H. J. 2013. "Employee Perception of CSR Activities: Its Antecedents and Consequences”, Journal of Business Research 66(10): 1716-1724.

51. Loveman, G. W. 1998. "Employee Satisfaction, Customer Loyalty, and Financial Performance: An Empirical Examination of the Service Profit Chain in Retail Banking", Journal of Service Research 1(1): $18-31$.

52. Lozano, J. M. 2008. "CSR or RSC? (Beyond the Humpty Dumpty Syndrome)", Society and Business Review 3(3): 191-206.

53. Luo, X.; Bhattacharya, C. B. 2006. "Corporate Social Responsibility, Customer Satisfaction, and Market Value", Journal of Marketing 70(4): 1-18.

54. Magrizos, S.; Apospori, E. 2015. SME CSR, Stakeholder Salience and Financial Performance: A Conditional Relationship. Paper presented at the Annual Meeting of the Academy of Management.

55. Maignan, I.; Ferrell, O. C. 2000. "Measuring Corporate Citizenship in Two Countries: The Case of the United States and France", Journal of Business Ethics 2: 283-297.

56. Maignan, I.; Ferrell, O. C. 2001. "Antecedents and Benefits of Corporate Citizenship: An Investigation of French Businesses", Journal of Business Research 51(1): 37-51.

57. Maignan, I.; Ferrell, O. C.; Ferrell, L. 2005. "A Stakeholder Model for Implementing Social Responsibility in Marketing”, European Journal of Marketing 39(9/10): 956-977.

58. Maignan, I.; Ferrell, O. C.; Hult, G. T. M. 1999. "Corporate Citizenship: Cultural Antecedents and Business Benefits”, Academy of Marketing Science Journal 27: 455-469.

59. Majeed, S. 2011. "The Impact of Competitive Advantage on Organizational Performance", European Journal of Business and Management 3(4): 191-196.

60. Margolis, E. Q.; Swetnam, T. W.; Allen, C. D. 2007. "A Stand-Replacing Fire History in Upper Montane Forests of the Southern Rocky Mountains", Canadian Journal of Forest Research 37(11): 2227-2241.

61. Margolis, J. D.; Elfenbein, H. A.; Walsh, J. P. 2008. Does it Pay to be Good? A Meta-analysis and Redirection of Research on the Relationship Between Corporate Social and Financial Performance. Working Papers. Harvard University.

62. Matzler, K.; Hinterhuber, H. H. 1998. "How to Make Product Development Projects More Successful by Integrating Kano's Model of Customer Satisfaction into Quality Function Deployment", Technovation 18(1): 25-38.

63. McWilliams, A.; Siegel, D. 2001. "Corporate Social Responsibility: A Theory of the Firm Perspective", The Academy of Management Review 26(1): 117-127.

64. Michelon, G.; Boesso, G.; Kumar, K. 2013. "Examining the Link between Strategic Corporate Social Responsibility and Company Performance: An Analysis of the Best Corporate Citizens", Corporate Social Responsibility and Environmental Management 20(2): 81-94.

65. Mohr, L. A.; Webb, D. J.; Harris, K. E. 2001. "Do Consumers Expect Companies to be Socially Responsible? The Impact of Corporate Social Responsibility on Buying Behavior”, The Journal of Consumer Affairs 35(1): 45-72.

66. Newell, P.; Muro, A. 2006. "Corporate Social and Environmental Responsibiity in Argentina: The Evolution of an Agenda", Journal of Corporate Citizenship 24(winter): 49-68. 
67. Ogrizek, M. 2002. "The Effect of Corporate Social Responsibility on the Branding of Financial Services", Journal of Marketing 6(3): 215-528.

68. Pan, J.-N.: Nguyen, H. T. N. 2015. "Achieving Customer Satisfaction Through Product-Service Systems", European Journal of Operational Research 247(1): 179-190.

69. Perrini, F.; Russo, A.; Tencati, A.; Vurro, C. 2012. "Deconstructing the Relationship Between Corporate Social and Financial Performance", Journal of Business Ethics: 1-18.

70. Peterson, D. K. 2004. "The Relationship between Perceptions of Corporate Citizenship and Organizational Commitment", Business \& Society 43(3): 296-319.

71. Pornchokchai, S. 2008. Housing Finance Mechanism in Thailand. Nairobi: UN-Habitat.

72. Porter, M. E.; Kramer, M. R. 2011. "Creating Shared Value", Harvard Business Review (JanuaryFebruary): 1-17.

73. Porter, M. E.; van der Linde, C. 1995. "Toward a New Conception of the Environmental Competitiveness Relationship", Journal of Economic Perspectives 9(4): 97-118.

74. Psomas, E. L.; Fotopoulos, C. V. 2010. “Total Quality Management Practices and Results in Food Companies", International Journal of Productivity and Performance Management 59(7): 668-687.

75. Rego, A.; Leal, S.; Cunha, M. P.; Faria, J.; Pinho, C. 2010. "How the Perceptions of Five Dimensions of Corporate Citizenship and Their Inter-inconsistencies Predict Affective Commitment", Journal of Business Ethics 94(1): 107-127.

76. Riketta, M. 2005. “Organizational Identification: A Meta-analysis", Journal of Vocational Behavior 66(2): 358-384.

77. Rowley, T.; Berman, S. 2000. "A Brand New Brand of Corporate Social Performance", Business \& Society 39(4): 397-418.

78. Russo, F. 2014. "What is the CSR's Focus in Healthcare?" Journal of Business Ethics: 1-12.

79. Saeidi, S. P.; Sofian, S.; Saeidi, P.; Saeidi, S. P.; Saaeidi, S. A. 2015. "How does Corporate Social Responsibility Contribute to Firm Financial Performance? The Mediating Role of Competitive Advantage, Reputation, and Customer Satisfaction", Journal of Business Research 68(2): 341-350.

80. Samy, M.; Odemilin, G.; Bampton, R. 2010. "Corporate Social Responsibility: A Strategy for Sustainable Business Success. An Analysis of 20 Selected British Companies", Corporate Governance 10(2): 203-217.

81. Scherer, A. G.; Palazzo, G. 2007. "Toward a Political Conception of Corporate Responsibility: Business and Society Seen from a Habermasian Perspective", Academy of Management Review 32(4): 10961120.

82. Sen, S.; Bhattacharya, C. B. 2001. "Does Doing Good Always Lead to Doing Better? Consumer Reactions to Corporate Social Responsibility", Journal of Marketing Research 38(2): 225-243.

83. Sheth, H.; Babiak, K. M. 2010. "Beyond the Game: Perceptions and Practices of Corporate Social Responsibility in the Professional Sport Industry”, Journal of Business Ethics 91: 433-450.

84. Shum, P.; Yam, S. 2011. "Ethics and Law: Guiding the Invisible Hand to Correct Corporate Social Responsibility Externalities", Journal of Business Ethics 98: 549-571.

85. Simon, D. H.; Gómez, M. I.; McLaughlin, E. W.; Wittink, D. R. 2009. "Employee Attitudes, Customer Satisfaction, and Sales Performance: Assessing the Linkages in US Grocery Stores", Managerial and Decision Economics 30(1): 27-41.

86. Singhapakdi, A.; Lee, D.-J.; Sirgy, M. J.; Senasu, K. 2015. "The Impact of Incongruity Between an Organization's CSR Orientation and Its Employees' CSR Orientation on Employees' Quality of Work Life", Journal of Business Research 68(1): 60-66.

87. Stasiulis, N. 2016. "On the Conception of the Creative in Natural Science and Philosophical Reflections Thereof”, Creativity Studies 9(1): 42-52.

88. Stites, J. P.; Michael, J. H. 2011. "Organizational Commitment in Manufacturing Employees: Relationships with Corporate Social Performance", Business \& Society 50(1): 50-70.

89. Stormer, F. 2003. "Making the Shift: Moving from "Ethics Pays" to an Inter-Systems Model of Business", Journal of Business Ethics 44(4): 279-289.

90. Swaminathan, V.; Groening, C.; Mittal, V.; Thomaz, F. 2014. "How Achieving the Dual Goal of Customer Satisfaction and Efficiency in Mergers Affects a Firm's Long-term Financial Performance", Journal of Service Research 17(2): 182-194.

91. Szántó, V. 2009. "The Death of Nature and the Birth of Ecology. Natural History and the Preconditions of Ecology in Early Modernity", Philobiblon 14: 45-59. 
92. Tench, R.; Sun, W.; Jones, B. 2012. "The Challenging Concept of Corporate Social Irresponsibility: An Introduction", in Critical Studies on Corporate Responsibility, Governance and Sustainability. Vol. 4. Corporate Social Irresponsibility: A Challenging Concept. Emerald Group Publishing Limited, 3-20.

93. Thornton, L.; Kvarnström, E. 2015. In Search of a Definition of CSR: A Study of Swedish Business Press during 2005-2014. Master's Thesis.

94. Turban, D. B.; Greening, D. W. 1997. "Corporate Social Performance and Organizational Attractiveness to Prospective Employees", Academy of Management Journal 40(3): 658-672.

95. Turker, D. 2009. "How Corporate Social Responsibility Influences Organizational Commitment", Journal of Business Ethics 89(2): 189-204.

96. Valentine, S.; Fleischman, G. 2008. "Ethics Programs, Perceived Corporate Social Responsibility and Job Satisfaction", Journal of Business Ethics 77(2): 159-172.

97. Van Beurden, P.; Gössling, T. 2008. "The Worth of Values - A Literature Review on the Relation Between Corporate Social and Financial Performance", Journal of Business Ethics 82(2): 407-424.

98. Van Knippenberg, D.; Sleebos, E. 2006. "Organizational Identification Versus Organizational Commitment: Self-definition, Social Exchange, and Job Attitudes", Journal of Organizational Behavior 27(5): 571-584.

99. Vveinhardt, J.; Andriukaitiene, R. 2016. "Model of Establishment of the Level of Management Culture for Managerial Decision Making with the Aim of Implementing Corporate Social Responsibility", Transformations in Business \& Economics 15(38B): 615-629.

100. Walsh, G.; Dinnie, K.; Wiedmann, K. P. 2006. "How Do Corporate Reputation and Customer Satisfaction Impact Customer Defection? A Study of Private Energy Customers in Germany", Journal of Services Marketing 20: 412-420.

101. Walsh, G; Mitchell, V. W.; Jackson, P. R. 2009. "Examining the Antecedents and Consequences of Corporate Reputation: A Customer Perspective”, British Journal of Management 20: 187-203.

102. Whitehead, A. N. 1978. Process and Reality: an Essay in Cosmology. New York: Free Press.

103. Williams, P.; Naumann, E. 2011. "Customer Satisfaction and Business Performance: A Firm-level Analysis", Journal of Services Marketing 25(1): 20-32.

104. Wood, D. J. 2010. "Measuring Corporate Social Performance: A Review", International Journal of Management Reviews 12(1): 50-84.

105. Zhao, H.-H.; Gao, Q.; Wu, Y.-P.; Wang, Y.; Zhu, X.-D. 2014. "What Affects Green Consumer Behavior in China? A Case Study From Qingdao", Journal of Cleaner Production 63: 143-151.

SAYEDEH PARASTOO SAEIDI, MOHD SHAHWAHID HAJI OTHMAN, DALIA ŠTREIMIKIENÉ, SAYYEDEH PARISA SAEIDI, ABBAS MARDANI, NERIJUS STASIULIS

\title{
Ekologijos filosofijos utilitarinis aspektas: korporaciju socialinès atsakomybès atvejis
}

\begin{abstract}
Santrauka
Šiuo tyrimu siekiame sujungti filosofinę perspektyvą ir kasdienybès praktinę ekologijos etiką su pragmatiškesne korporacijų socialinės atsakomybės (KSA) sąvoka. Parodome, kad pastarosios svarba remiasi subjekto ir objekto skirties atsisakymu ir tiek asmeninès, tiek kultūrinès ekologinès sąmonès, kylančios iš žmogaus ir gamtos vienybės sampratos, raida. Šis sąmonès filosofinis pokytis reikšmingas ir naudingumo požiūriu. Todèl tiriame, ar santykị tarp korporacijų socialinès atsakomybès ir įmonès pardavimų augimo medijuoja konkurencinis pranašumas ir ar darbuotojų individualus kasdienis suvokimas ir jų įsitikinimai apie socialinę atsakomybę atlieka moderuojantį vaidmenį KSA pardavimų augimo plotmejje. Analizès metu atskleistas ryšys tarp KSA ir pardavimų augimo bei pozityvus KSA poveikis pardavimų augimui, kurị teigiamai moderuoja darbuotojų individualūs i̊sitikinimai apie socialinę atsakomybę, kylančią iš ekologinès sąmonès.
\end{abstract}

Raktažodžiai: darbuotojų individualūs ịsitikinimai, ekologijos filosofija, ekologinè sąmonè, konkurencinis pranašumas, korporacijų socialinė atsakomybe் 